\title{
In vitro Antimicrobial and Antioxidant Studies on N-(2- hydroxylbenzylidene) pyridine -2-amine and its M(II) Complexes
}

\author{
${ }^{*} \mathrm{U}$. Sani, ${ }^{1} \mathrm{H} . \mathrm{U} \mathrm{Na}$ 'ibi and ${ }^{2} \mathrm{~S}$.A Dailami \\ ${ }^{1}$ Department of Pure and Industrial Chemistry, Bayero University, PMB 3011, Kano, Nigeria \\ bDepartment of Chemistry, Federal University Lokoja, PMB 1154, Lokoja, Kogi, Nigeria \\ [Corresponding Author: E-mail: sumar.chm@buk.edu.ng; $\mathbf{\nabla}+2348035370070]$
}

\section{ABSTRACT}

A tridentate ligand $\mathrm{N}-(2-$ hydroxybenzylidene)pyridine-2-amine has been prepared by condensation of salicylaldehyde and 2-aminopyridine in absolute ethanol. $\mathrm{M}(\mathrm{II})$ complexes (M= Mn and $\mathrm{Ni}$ ) of the ligand were also prepared, recovered by filtration and purified by recrystallization in absolute methanol. Characterization of the prepared compounds was done on the basis of FTIR spectroscopy, solubility test, melting point/decomposition temperature, conductivity and magnetic susceptibility measurements. Job's method of continuous variation was used to determine the number of ligands coordinated to the metal ions. The result indicated 1:2 Metal (II) to ligand ratio in both the complexes. Appearance of a sharp peak at $1596 \mathrm{~cm}^{-1}$ in the FTIR spectra of the ligand indicated the formation of the azomethine (-C=N-) bond. This peak shifted to lower frequencies $\left(1590 \mathrm{~cm}^{-1}\right.$ and $\left.1557 \mathrm{~cm}^{-1}\right)$ in the spectra of the $\mathrm{Mn}^{2+}$ and $\mathrm{Ni}^{2+}$ complexes respectively due to coordination of the azomethine nitrogen to the metal ions. Antimicrobial activities of the ligand and the complexes were studied on Staphylococcus aureus, Escherichia coli, Klebsiella pneumonia, Aspergillus funigathus and Mucor sp. isolates using disc diffusion method. The results obtained indicated that the test compounds are active against most of the tested isolates. Antioxidant activity of the compounds was tested using 2,2'-diphenyl-1-picrylhydrazyl (DPPH) radicals scavenging method. The lower IC $\mathrm{C}_{50}$ value $(2.27 \mu \mathrm{g} / \mathrm{ml})$ obtained in the ligand, by probit analysis using SPSS 16.0, indicates its high antioxidant property.

Keywords: Salicylaldehyde, Azomethine, Reflux, Antimicrobial and Antioxidant.

\section{INTRODUCTION}

Azomethines are aldehyde or ketone like compounds in which the carbonyl $(\mathrm{C}=0)$ group is replaced by an imine (-C=N-) group (Usharani et al., 2013). These compounds are reported as powerful ligands having high affinity to coordinate to transition metal ions (Aliyu and Danlami, 2012). Polydentate azomethines have good chelating property and can form stable complexes with transition metal ions (Raziah and Saed, 2012). Azomethines that co-ordinate through the $\mathrm{O}$ atom of the de -protonated phenolic $-\mathrm{OH}$ group and the $\mathrm{N}$ atom of imine group have been well researched and reported (Workuet al., 2002) in several literature. Such compounds play a vital role in co-ordination chemistry (Gamet and Reedsk, 2006) and are reported to possess antifungal, antibacterial, antioxidant, antiviral and herbicidal activities
(Sigh et al., 2007; Chandra and Sangeetika, 2004).

It is strongly believed that the specific $-\mathrm{C}=\mathrm{N}$ group (azomethine) is an important structural requirement for the bioactivity of Schiff's bases. Schiff's bases are usually synthesized from the condensation of primary amines and active carbonyl groups by nucleophilic addition forming a hemiaminal, followed by a dehydration to generate an imine. Mechanistically, the formation of an imine involves two steps (Fig. 1). First, the amine nitrogen acts as a nucleophile, attacking the electrophilic carbonyl carbon of aldehydes or ketones. In the next step (Fig. 1), the nitrogen is deprotonated, and the electrons from this $\mathrm{N}-\mathrm{H}$ bond push the oxygen off the carbon, leaving a compound with a $\mathrm{C}=\mathrm{N}$ double bond (an imine) and a water molecule displaced. 


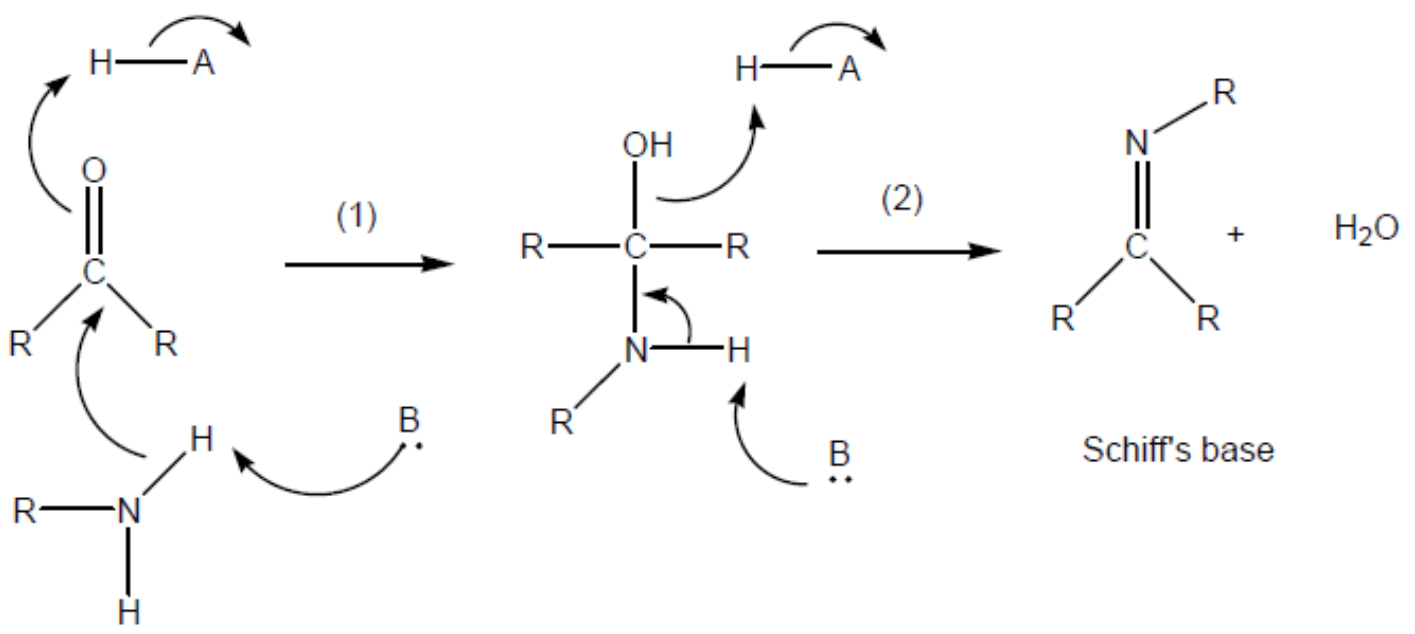

Figure 1: Mechanism of Schiff base (imine) Formation

\section{MATERIALS AND METHOD}

Reagents used for this study were of Analar grade purchased from Sigma Aldrich and used without further purification. Shimadzu FTIR8400S spectrophotometer was used for the spectral studies. Bacterial and fungal isolates (Bacteria: Staphylococcus aureus, Escherichia coli and Klebsiella pneumonia. Fungi: Aspergillus fumigatus and Mucor species) were purchased from Aminu Kano Teaching Hospital (AKTH) Kano, and identified at the Department of Microbiology, Bayero University Kano. Nutrient Agar (NA) and Potato Dextrose Agar (PDA) were used as bacterial and fungal media respectively.

\section{Preparation of the Ligand}

Hot ethanolic solution of 2-amino pyridine $(10 \mathrm{mmol}, \quad 0.94 \mathrm{~g})$ was added slowly to salicyladehyde $(10 \mathrm{mmol}, 1.22 \mathrm{~g})$ in $20 \mathrm{ml}$ ethanol. The mixture was refluxed on a hot plate for $2 \mathrm{~h}$ with constant stirring. On cooling, orange precipitate was obtained, separated from the reaction mixture by filtration and washed several times with cold water and then recrystallized from methanol and dried over phosphorous pentaoxide for three (3) days (Chundawat et al, 2014). Percentage yield of the product was calculated using equation (1).<smiles>O=Cc1ccccc1O</smiles><smiles>Nc1ccccn1</smiles><smiles>[R][R4]([H])(C)C</smiles>

Scheme 1: Preparation of N-(2-hydroxylben zylidene) Pyridine-2-amine

$\%$ Yield $=($ Actual Mass of the Product obtained $/$ Theoretical Mass $) \times 100$ 


\section{Nigerian Journal of Basic and Applied Science (June, 2017), 25(1): 81-88}

\section{Preparation of the Complex}

The complexes were prepared by modifying the procedure described by Sani and Dailami (2015). Solution of the metal(II) chloride $(10 \mathrm{mmol})$ in boiling ethanol was added drop wise to hot ethanolic solution $(20 \mathrm{mmol}, 3.96 \mathrm{~g})$ of the ligand. This mixture was refluxed on a hot plate for three (3) hours with constant stirring. The resulting solution was concentrated to half its original volume and cooled. The crystals formed were separated by filteration, washed with ethanol, recrystallized from methanol and dried over phosphorous pentaoxide for two (2) days. Percentage yield of the products were obtained using equation (1).

$$
\text { Lingard }+\mathrm{MCl}_{2} \cdot \mathrm{XH}_{2} \mathrm{O} \underset{3 \mathrm{~h}}{\underset{\mathrm{h}}{\longrightarrow}} \mathrm{M}(\mathrm{II}) \text { complex }
$$

$\mathrm{M}=\mathrm{Mn}^{2+}$ or $\mathrm{Ni}^{2+} ; \mathrm{X}=4$ or 6 .

Scheme 2: Preparation of the M(II) Complexes

\section{Antimicrobial Activity Test}

The in vitro antibacterial and antifungal activities of the ligand and the metal(II) complexes were tested against three (3) bacteria i.e. Escherichia coli, Klebsiella pneumonia and Staphylococcus aureus and two (2) fungi viz; Aspergillus fumigatus and Mucor sp. using disc diffusion method (Sharma et al., 2009). The suspension of each microorganism was smeared on the surface of prepared agar media already poured into petri dishes by means of sterile swabs. Different concentrations $(15,30$ and $60 \mu \mathrm{g} / \mathrm{disc})$ of the ligand and the metal(II) complexes in DMSO were prepared through serial dilution and placed on the culture media before incubation at suitable optimum temperature for $24 \mathrm{~h}$. Activities were determined by measuring (in $\mathrm{mm}$ ) the diameter of the zone showing complete inhibition and compared with standard antibacterial (Gentamicin) and antifungal (ketoconazole) drugs respectively. Nutrient agar and potato dextrose agar were used as bacterial and fungal media respectively.

\section{Antioxidant Activity Test}

The free radical scavenging activity of the ligand and its Metal (II) complexes against 2,2'-diphenyl1-picrylhydrazine (DPPH) radical was determined according to the method described by Lu et al., (2013). Stock solutions $(1.0 \mathrm{mg} / \mathrm{ml})$ of the test compounds were prepared followed by serial dilution to obtain the following concentrations; $1000,500,250,100,50$ and $10 \mu \mathrm{g} / \mathrm{ml}$. DPPH methanolic solution $(50 \mu \mathrm{M})$ was prepared and added to the sample solutions $(0.1 \mathrm{ml}$ each) and allowed to react at room temperature for $30 \mathrm{~min}$ in dark. The absorbance of the mixtures was measured at $517 \mathrm{~nm}$. Butylated hydroxytoluene was used as positive control. Lower absorbance of the reaction mixture indicates higher free radical scavenging activity and vice versa.

Inhibitions of DPPH radical in percent (\%) were calculated using the formula:

$$
1 \%=\frac{A_{\text {control }}-A_{\text {sample }}}{A_{\text {control }}} \times 100
$$

Where, $A_{\text {control }}=$ absorbance of the control reaction (containing all reagents except the test compound)

$A_{\text {sample }}=$ absorbance of the reagents with the test compound.

The sample concentration that provides 50\% inhibition $\left(\mathrm{IC}_{50}\right)$ was determined using SPSS 16.0 software.

\section{RESULTS AND DISCUSSION}

$\mathrm{N}$-(2-hydroxylbenzylidene) pyridine-2-amine Schiff base ligand and its $\mathrm{Mn}^{2+}$ and $\mathrm{Ni}^{2+}$ complexes were prepared as orange, brown and green precipitates respectively. The percentage yields of the compounds are presented in Table 1. The metal chelates were found to be more thermally stable than the free ligand which may be attributed to formation of stable complexes. The complexes were paramagnetic (Sani and Dailami, 2015) with less than three unpaired electrons in each, and nonelectrolytes (Geary, 1971) on the basis of molar 
Sani etal: In vitro Antimicrobial and Antioxidant Studies on N-(2- hydroxylbenzylidene) pyridine......

conductance values (Table 1) which are too low for a 1:2 electrolytic in methanol.

All the compounds were insoluble in distilled water and DMF, soluble in methanol, ethanol and
DMSO while slightly soluble in acetone (Table 2). The solubility of the compounds in protonic solvents may be attributed to the formation of hydrogen bonds between the compounds and the solvents.

Table1: Physicochemical and Analytical Data of the Ligand and M(II) Complexes

\begin{tabular}{ccccccc}
\hline Compound & $\begin{array}{c}\text { Molecular } \\
\text { Formula }\end{array}$ & Colour & $\begin{array}{c}\text { Yield } \\
(\%)\end{array}$ & $\begin{array}{c}\text { Melting } \\
\text { Temp. } \\
\left({ }^{\circ} \mathrm{C}\right)\end{array}$ & $\begin{array}{c}\text { Molar } \\
\text { Conductivity } \\
\left(\text { ohm }^{-1} \mathrm{~cm}^{2} \mathbf{m o l}^{-1}\right)\end{array}$ & $\begin{array}{c}\text { Magnetic } \\
\boldsymbol{\mu}_{\text {eff }}(\mathrm{B} . \mathrm{M})\end{array}$ \\
\hline Ligand $[\mathrm{L}]$ & $\mathrm{C}_{12} \mathrm{H}_{10} \mathrm{~N}_{2} \mathrm{O}$ & Orange & 89 & 68 & - & - \\
{$\left[\mathrm{MnL}_{2}\right]$} & {$\left[\mathrm{C}_{24} \mathrm{H}_{18} \mathrm{~N}_{4} \mathrm{O}_{2} \mathrm{Mn}\right]$} & Brown & 42 & 195 & 84 & 5.37 \\
{$\left[\mathrm{NiL}_{2}\right]$} & {$\left[\mathrm{C}_{24} \mathrm{H}_{18} \mathrm{~N}_{4} \mathrm{O}_{2} \mathrm{Ni}\right]$} & Green & 86 & 219 & 58 & 2.51
\end{tabular}

$\mathrm{L}=\mathrm{N}$-(2-hydroxylbenzylidene) pyridine-2-amine

Table 2: Solubility of the Ligand and $M(I I)$ Complexes

\begin{tabular}{|c|c|c|c|}
\hline Solvent & $\begin{array}{c}\text { Ligand } \\
{[\text { L] }}\end{array}$ & {$\left[\mathrm{MnL}_{2}\right]$} & {$\left[\mathrm{NiL}_{2}\right]$} \\
\hline Dist. $\mathrm{H}_{2} \mathrm{O}$ & IS & IS & IS \\
\hline Methanol & $S$ & $S$ & $S$ \\
\hline Ethanol & $S$ & $S$ & $S$ \\
\hline Chloroform & $S$ & SS & SS \\
\hline $\mathrm{CCl}_{4}$ & SS & IS & IS \\
\hline Acetone & SS & SS & SS \\
\hline DMF & IS & IS & IS \\
\hline DMSO & $S$ & $S$ & $S$ \\
\hline $\begin{array}{l}\mathrm{L}=\mathrm{N}-(2-\mathrm{hy} \\
\mathrm{S}=\text { Soluble } \\
\text { Insoluble }\end{array}$ & cylbenz & $\begin{array}{l}\text { ne) py } \\
\text { ly Soll }\end{array}$ & $\begin{array}{l}-2-a m \\
\text { and }\end{array}$ \\
\hline
\end{tabular}

The FTIR vibration frequencies of the compounds were recorded on Shimadzu 8400S in the range $4000-700 \mathrm{~cm}^{-1}$ and presented in (Table 3). Sharp peaks at 1596, 1590 and $1557 \mathrm{~cm}^{-1}$ were observed in the spectra of the ligand, $\mathrm{Mn}^{2+}$ and $\mathrm{Ni}^{2+}$ complexes respectively. These bands are attributed to the presence of azomethine $(-\mathrm{C}=\mathrm{N}-)$ bonds (Sani and Aliyu, 2012). A band at $3054 \mathrm{~cm}^{-}$ ${ }^{1}$ was observed in the spectra of the ligand which can be assigned to the presence of phenolic $-\mathrm{OH}$ group. This band disappeared in the spectra of the $M(I I)$ complexes due to deprotonation and subsequent covalent bond formation between the phenolic oxygen and the metals. Two distinct peaks in the range of $700-800 \mathrm{~cm}^{-1}$ were observed in the spectra of the complexes. These bands corresponds to the $\mathrm{U}(\mathrm{M}-\mathrm{N})$ stretching vibrations for the azomethine and hetero $\mathrm{N}$ atoms respectively (Table 3 ).

In vitro antibacterial and antifungal activity results were reported in Tables 4 and 5 respectively. Highest antibacterial activity was observed in the ligand against the gram positive (Staphyloccocus 
aureus) bacterium. It was observed that chelation did not improve activity in case of the gram positive bacterium while the complexes show higher activity against the gram negative bacteria (Escherichia coli and Klebsiella pneumoniae). The higher activities recorded despite usual resistance by gram negative bacteria is of great interest and pave way for further investigation on other isolates. Only Escherichia coli resisted the ligand and $\mathrm{Mn}$ complex at lower $(15 \mu \mathrm{g} / \mathrm{disc})$ concentration (Table 4). These activities may be attributed to overtone's concept of lipid permeability (Kalaivani et al., 2012) and Tweedy's chelation (Thangadurai and Natarajan, 2001) theories respectively.

The fungal isolates resisted some of the test compounds at lower concentrations. All the test compounds were active against the fungi at $60 \mu \mathrm{g} / \mathrm{disc}$ (Table 5). This resistance therefore calls for further investigations such as minimum inhibition concentration (MIC) and minimum fungicidal concentration (MFC) on the isolates. Activities of the test compounds were found to be reasonably comparable to the activities of the standards used

Table 3: FTIR Vibration Frequencies of the Ligand and the M(II) Complexes

\begin{tabular}{ccccc}
\hline Compound & $\begin{array}{c}\mathbf{U}(\mathbf{C = N}) \\
\mathbf{c m}^{-1}\end{array}$ & $\begin{array}{c}\mathbf{U}(-\mathrm{OH}) \\
\mathbf{c m}^{-1}\end{array}$ & $\begin{array}{c}\mathbf{u}(\mathbf{M}-\mathrm{N}) \\
\mathbf{c m}^{-1}\end{array}$ & $\begin{array}{c}\mathbf{U}\left(\mathbf{M}-\mathbf{N}^{\prime}\right) \\
\mathbf{c m}^{-1}\end{array}$ \\
\hline Ligand [L] & 1596 & 3054 & - & - \\
{$\left[\mathrm{MnL}_{2}\right]$} & 1590 & - & 761 & 758 \\
{$\left[\mathrm{NiL}_{2}\right]$} & 1557 & - & 760 & 700 \\
\hline
\end{tabular}

$\mathrm{L}=\mathrm{N}$-(2-hydroxylbenzylidene) pyridine-2-amine; $N^{\prime}$ is an hetero atom

Table 4: Antibacterial Activities of the Ligand and M(II) Complexes

\section{Bacterial Isolates}

\begin{tabular}{|l|ccc|ccc|ccr|}
\hline & \multicolumn{3}{|c|}{ Staphyloccocus aureus } & \multicolumn{3}{|c|}{ Escherichia coli } & \multicolumn{3}{|c|}{ Klebsiella pneumoniae } \\
$\begin{array}{l}\text { Concentrations } \\
(\mu \mathrm{g} / \mathrm{disc})\end{array}$ & 15 & 30 & 60 & 15 & 30 & 60 & 15 & 30 & 60 \\
\hline
\end{tabular}

Compounds Zone of Inhibition (mm)

\begin{tabular}{|c|c|c|c|c|c|c|c|c|c|}
\hline $\begin{array}{l}\text { Ligand } \\
{[\mathrm{L}]}\end{array}$ & 11 & 16 & 20 & $\mathrm{NZI}$ & 9 & 11 & 10 & 12 & 15 \\
\hline$\left[\mathrm{MnL}_{2}\right]$ & 8 & 10 & 13 & $\mathrm{NZI}$ & 10 & 12 & 12 & 15 & 19 \\
\hline [NiL2] & 8 & 12 & 16 & 7 & 9 & 11 & 10 & 12 & 14 \\
\hline $\begin{array}{c}\text { Standard } \\
(2 \mathrm{mg} / \mathrm{ml})\end{array}$ & & & & & 30 & & & 26 & \\
\hline
\end{tabular}

$\mathrm{L}=\mathrm{N}$-(2-hydroxylbenzylidene) pyridine-2-amine; KEY: NZI= No Zone of Inhibition 
Sani etal: In vitro Antimicrobial and Antioxidant Studies on N-(2- hydroxylbenzylidene) pyridine......

Table 5: Antifungal Activities of the Ligand and M(II) Complexes

\begin{tabular}{|c|c|c|c|c|c|c|}
\hline \multirow[b]{3}{*}{$\begin{array}{l}\text { Concentrations } \\
\text { ( } \mu \text { g/disc) }\end{array}$} & \multicolumn{4}{|c|}{ Fungal Isolates } & & \\
\hline & \multicolumn{3}{|c|}{ Aspergillus fumigatus } & \multicolumn{3}{|c|}{ Mucor species } \\
\hline & 15 & 30 & 60 & 15 & 30 & 60 \\
\hline Compounds & \multicolumn{5}{|c|}{ Zones of Inhibition (mm) } & \\
\hline $\begin{array}{l}\text { Ligand } \\
\text { [L] }\end{array}$ & $\mathrm{NZI}$ & NZI & 9 & NZI & 10 & 12 \\
\hline$\left[\mathrm{MnL}_{2}\right]$ & 9 & 11 & 14 & NZI & 10 & 14 \\
\hline$\left[\mathrm{NiL}_{2}\right]$ & NZI & 9 & 12 & 9 & 11 & 14 \\
\hline $\begin{array}{l}\text { Standard } \\
(5 \mathrm{mg} / \mathrm{ml})\end{array}$ & & 38 & & & 27 & \\
\hline
\end{tabular}

$\mathrm{L}=\mathrm{N}-(2$-hydroxylbenzylidene) pyridine-2-amine; NZI= No Zone of Inhibition

DPPH radical scavenging (antioxidant) activities of the compounds were reported in (Table 6). The ligand showed very good radical scavenging potential followed by the Mn complex. The lower $\mathrm{IC}_{50}$ value of $2.27 \mu \mathrm{g} / \mathrm{ml}$ obtained in the ligand indicates its higher antioxidant property compared to the $\mathrm{IC}_{50} \mathrm{Value}$ of $12.95 \mathrm{\mu g} / \mathrm{ml}$ (Fig. 2) obtained in the butylated hydroxytoluene (BHT) employed as a positive control. This higher radical scavenging property of the ligand may be attributed to the presence of acidic hydrogen in the phenolic $-\mathrm{OH}$ as well as the presence of hetero atom attached to the ligand (Dailami et al., 2016).

Table 6: Radical Scavenging (Antioxidant) Activity of the Ligand and M(II) Complexes

\begin{tabular}{|c|c|c|c|c|}
\hline \multirow{2}{*}{$\begin{array}{l}\text { Concentration } \\
(\mu \mathrm{g} / \mathrm{ml})\end{array}$} & \multicolumn{4}{|c|}{ \% Inhibition } \\
\hline & Ligand [L] & {$\left[\mathrm{MnL}_{2}\right]$} & {$\left[\mathrm{NiL}_{2}\right]$} & $\begin{array}{l}\text { Control } \\
\text { (BHT) }\end{array}$ \\
\hline 1000 & 95.83 & 91.72 & 47.52 & 92.69 \\
\hline 500 & 95.14 & 89.84 & 35.58 & 91.38 \\
\hline 250 & 94.32 & 74.28 & 41.74 & 90.82 \\
\hline 100 & 94.61 & 67.22 & 28.47 & 86.66 \\
\hline 50 & 94.79 & 52.76 & 89.11 & 73.63 \\
\hline 10 & 60.94 & 35.31 & 91.85 & 40.51 \\
\hline $\mathrm{IC}_{50}$ & $2.27 \mu \mathrm{g} / \mathrm{ml}$ & $32.56 \mu \mathrm{g} / \mathrm{m}$ & $228.57 \mu \mathrm{g} / \mathrm{m}$ & $12.95 \mu \mathrm{g} / \mathrm{m}$ \\
\hline
\end{tabular}

$\mathrm{L}=\mathrm{N}$-(2-hydroxylbenzylidene) pyridine-2-amine 


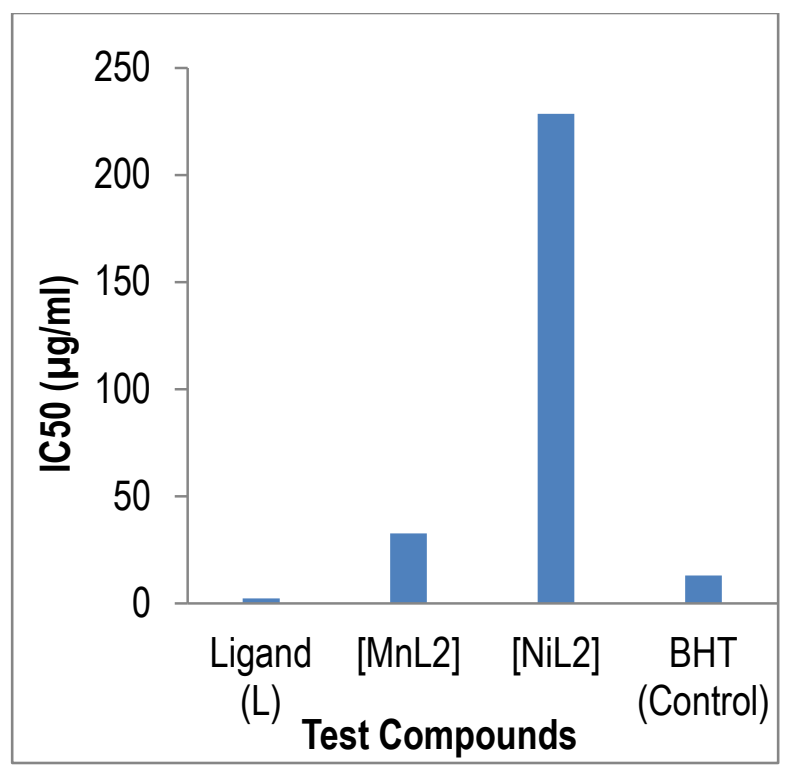

Figure 2: Plot of $\mathrm{IC}_{50}$ of the ligand and Complexes Compared with BHT

\section{CONCLUSION}

A tridentate ligand $\mathrm{N}-(2-$ hydroxybenzylidene)pyridine-2-amine and its octahedral $\mathrm{Mn}^{2+}$ and $\mathrm{Ni}^{2+}$ complexes were successfully prepared, characterized and reported. The compounds showed good antibacterial and antifungal properties. Lower $\mathrm{IC}_{50}$ value obtained from the DPPH radical scavenging study of the ligand suggests its potentiality for further antioxidant activity investigation.

\section{REFERENCES}

Aliyu H. N. and Sani U. (2012). Synthesis, Charterization and Biological Activity of Manganese (II), Iron(II), Cobalt(II), Nickel(II) and Copper(II) Schiff base Complexes Against Multidrug Resistant Bacterial and Fungal Pathogens, International Research Journal of Pharmacy and Pharmacology, 2(2): 40 44

Aliyu. H. N. and Danlami, A. (2012). Spectral and Potentiometric Studies on Manganese (II) and Cobalt (II) complexes with Schiff Base Derived from 2Thiophenecarboxylaldehyde and 2aminobenzoic acid, Asian Research
Publishing Network- Journal of Science and Technology, 2:(3),147-154.

Chandra, S., and Sangeetika (2004). Synthesis Characterization and Thermal Analysis of $\mathrm{New} \mathrm{Cu}(\mathrm{II})$ with hydrazide ligands, European Journal of Chemistry, 7(51):278-282.

Chundawat N S., Mayank P. and Dangi, R. R. (2014). Synthesis and characterization of Schiff bases, international journal of Pharmaceutical Science Research, 4(2):25-26.

Dailami, S.A, Onakpa, S.A and Funtua M.A (2016). $\mathrm{Fe}(\mathrm{III})$ and $\mathrm{Cr}(\mathrm{III})$ Complexes with Phenolic Schiff Base: Synthesis, Physico-Chemical Characterisation, Antimicrobial and Antioxidant Studies IOSR Journal of Applied Chemistry (IOSR-JAC), 9(9): 18-23

Gamet, P. Reedsk, J., Eur. J. (2006). Synthesis and characterization of Schiff base ligands. In Organic Chemistry, 29: 1-10.

Geary, W. J., (1971), "The Use of Conductivity Measurement in Organic Solvents for the Characterization of Coordination Compounds", Coordination Chemistry Review, 7: 82-110.

Kalaivani S., Priya N.P. and Arunachalam S.(2012): Schiff bases facile Synthesis Spectral Charaterization and Biocidal Studies, International Journal of Applied Biology and Pharmaceutical Technology, 3: $19-23$

Lu Y.R., Aktumsek A. and Foo L.Y. (2013). Antioxidant and Radical Scavenging Activities of Polyphenols from Apple Pomace, Food Chemistr, 68: 81 - 85

Raziyah A. A. and Saeid A. (2012), Synthesis, spectroscopy, thermal analysis, magnetic properties and biological activity studies of $\mathrm{Cu}(\mathrm{II})$ and $\mathrm{Co}(\mathrm{II})$ complexes with Schiff base Dye ligands Molecules 17, 64346448.

Sani, U and Dailami, S.A (2015).Synthesis, Characterization, Antimicrobial Activity and Antioxidant Studies of Metal (II) Complexes of Schiff Base Derived from 2 
Sani etal: In vitro Antimicrobial and Antioxidant Studies on N-(2- hydroxylbenzylidene) pyridine......

- Hydroxy -1- Naphthaldehyde and Hydrazine Monohydrate, Chem Search Journal, 6(2): 35-41.

Sharma, K., Swami, M., Singh, R.,Fahmi, N. and Singh, R.V. (2009). "Coordination chemistry of palladium(II) and platinum(II) complexes with bioactive Schiff bases: Synthetic, spectral and biocidal aspects", Russian Journal of Coordination chemistry, 35(2).142-148.

Thangadurai T.D. and Natarajan K. (2001). MixedLigand Complexes of Ruthenium(II) containing $\quad \alpha, \beta$-unsaturated $\quad-\beta$ ketoamines and their antibacterial activity, Transition Metal Chemistry, 26(4 -5): $500-504$.
Usharani M, Akila E, Ashokan, R and Rajavel R. (2013). Pharmacological properties of Schiff base metal complexes derived from substituted pyridine and aromatic amine, International Journal of Pharmaceutical Science and Health Care, 5(3):I-II.

Worku, D., Negussie, M., Raju, V.J.T. and Negussie, R. (2002). Synthesis and study of Schiff base ligands. Bulletin of the Chemical Society of Ethiopia, 17:30. 